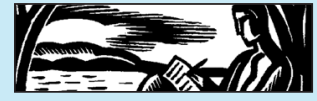

\title{
Complicating the Obvious: Teaching Life Writing at the University of Salzburg
}

\author{
Sarah Herbe
}

University of Salzburg

I taught my first course on women's life writing at the department of English and American Studies (University of Salzburg) in 2010 and have since taught others on autobiographies as well as biographies. Some of my colleagues regularly teach courses on life writing as well, so our students have a fair chance to become exposed to one or the other course dealing with life writing in the course of their bachelor, teacher-training or master studies programmes. Experience has shown that students tend to approach auto/biographies as if they were the most straightforward genres in the world, which makes dealing with examples of life writing in university contexts slightly puzzling for some of them, particularly when they are expected to approach life-writing texts critically with a set of methodological tools informed by critical theory. Also, students often do not know the difference between biographical and autobiographical writing to begin with. To draw their attention to the differences between these forms of life writing and to make them aware that both usually involve processes of selection, construction as well as a particular perspective, I start my courses on life writing with a simple but effective exercise.

In our first session, I ask students to form pairs and talk about who they are, why they have chosen the course, and whether they read auto/ biographies. After five minutes, they briefly introduce their partner to the whole group. At the end of this exercise, I alert them to the fact that they have just told stories about themselves as well as about the other person, and therefore produced brief oral autobiographical and biographical texts respectively. Even though it is an artificial situation and students only have very limited time at their disposal, reflecting on the first step of talking about themselves draws their attention to the fact that what they 
choose to tell the other person depended on the prompts they received at the beginning of the exercise, the setting they found themselves in, and the way they wanted to be seen by the other person, as well as by the whole group. This experience ideally leads to the insight that autobiographical writing is always to a certain extent determined by the conditions of production (including audience expectations), the autobiographer's motivation for presenting him- or herself to the outside world, as well as pre-existing models for talking about oneself. This insight forms the starting point for future discussions of autobiographical acts and autobiographical subjects, based on a reading of the respective chapters in Sidonie Smith and Julia Watson's Reading Autobiography.

Reflecting on the second step of the exercise, I tell students that everyone basically created a miniature biography: they selected some pieces of information from everything they learned about the other person, and they imposed a particular structure on the information they gleaned from the conversation. Also, even if they did not substantially alter any of the information provided by the other person, by using their own words and by changing the pronouns, they will have brought in their own perspective to a certain extent. This exercise therefore also creates awareness that biographies are products of collecting, selecting and arranging material in a particular way, and that they will be influenced by the perspective of the person who writes them.

This exercise can be expanded in the following way: three students form a group and introduce themselves. Then, everyone in the group puts the information about the other two students into writing. Comparing the two versions will highlight the fact that if two people write the biography of the same person, even if their works are based on similar material, the stories will never be exactly the same. This exercise particularly draws attention to the role of the life writer. Also, it makes plain that biographical accounts differ from autobiographical accounts.

The insights gained from this exercise formed the basis for many of the questions we asked in my proseminar on "Literature and Culture: The Art of Biography", where we considered, for example, the varying roles of biographers, their tasks and skills, as well as models for writing biographies. Among the theoretical texts we read together were Jeanne W. Halpern's "Biographical Images: Effects of Formal Features on the Way We See a Life" (1978), Lynn Z. Bloom's "Popular and Super-Pop Biographies: Definitions and Distinction" (1990) and Wilson Snipe's "Authorial Typology in Literary Biography" (1990). Students then applied these theoretical concepts in their readings of a selection of biographical texts ranging from chapters from James Boswell's Samuel Johnson and Elizabeth Gaskell's The Life of Charlotte Brontë to Peter Ackroyd's Chaucer (2005) and Chas Newkey-Burden's Adele: The Biography (2012). 
In courses dealing particularly with autobiographies I have further found it helpful to start with a discussion of fake autobiographies and think about why we, as readers, are so outraged when it comes to light that a certain autobiography is not actually "true". This question is useful for teasing out implicit genre expectations harboured by students when they approach life-writing texts and forms a good basis for introducing them to Philippe Lejeune's idea of the autobiographical pact, as well as for discussing concepts of truth and authenticity in autobiography.

The integration of digital tools such as blogs and online discussion forums does not only have the advantage of catering to the needs of different types of learners and drawing students' attention to the fact that most of them are engaged in producing life-writing texts of some kind when they present stories about themselves on social media (see Herbe 2018), but also highlights the importance of the form and materiality in which we encounter life-writing texts. If students are willing to do this, building on the starting exercise of the first session, they can proceed to analyse their social media presentation as forms of life writing. Also, examples of digital life writing, such as Jeanette Winterson's column (see Herbe 2017), can become primary texts for analysis in life-writing courses.

To move on to other texts that lend themselves well to discussions: Winterson's Why be Happy When You Could be Normal? (2011) has proven very popular with students (more so than her monthly online column, actually). It offers itself for a variety of discussions: it is an adoption narrative, it negotiates the author's gender and artistic identity, and it addresses traumatic experience with a humorous attitude. Also, it can be compared to Winterson's autobiographical novel Oranges Are Not The Only Fruit (1985), which will lead to discussions about the generic boundaries/differences/similarities between novels and autobiographical texts. The question of how autobiographies and novels intersect can be further explored with the help of The Jive Talker, or, How to Get a British Passport (2008) by Malawi-born writer and conceptual artist Samson Kambalu. His book does not only lend itself to discussions about identity formation and migration: since it is labelled as a memoir in the UK and the US but marketed as a novel for the German-speaking world, students will have to go beyond the text and think about advertising strategies in the framework of the book market. These can be further addressed by including a popular biography such as Chas Newkey-Burden's Adele, which is largely based on publicly available coverage of the singer and appeared at the height of her popularity in 2012. Considering such a text will also help make obvious the different methods and motivations behind academically researched biographies on the one hand, and quickly written, popular biographies of celebrities on the other. 


\section{WORKS CITED}

Ackroyd, Peter. Chaucer. London: Vintage, 2005.

Bloom, Lynn Z. "Popular and Super-Pop Biographies: Definitions and Distinctions." Biography 3.3 (1980): 225-239.

Boswell, James. The Life of Samuel Johnson. London: Baldwin and Son, 1791.

Gaskell, Elizabeth. The Life of Charlotte Brontë. London: Smith, Elder \& Co., 1857.

Halpern, Jeanne W. "Biographical Images: Effects of Formal Features on the Way We See a Life." Biography 1.4 (1978): 1-14.

Herbe, Sarah. "Online Self-Presentation and Promotion in Jeanette Winterson's Column (2000-2014)." Eds. Sarah Herbe and Gabriele Linke. British Autobiography in the 20th and 21st Centuries. Heidelberg: Winter, 2017. 59-77.

Herbe, Sarah. "Teaching Life Writing in a Blended Learning Environment." a/b: Auto/biography Studies 33.1 (2018): 221-229.

Kambalu, Samson. The Jive Talker: Or, How to Get a British Passport. London: Jonathan Cape, 2008.

Lejeune, Philippe. On Autobiography. Theory and History of Literature. Minneapolis: Univ. of Minnesota Pr., 1989.

Newkey-Burden, Chas. Adele: The Biography. London: John Blake, 2012.

Smith, Sidonie, and Julia Watson. Reading Autobiography: Interpreting Life Narratives. University of Minnesota Press, 2010.

Snipes, Wilson. "Authorial Typology in Literary Biography." Biography 13.3 (1990): 235-250.

Winterson, Jeanette. Oranges Are Not the Only Fruit. London: Vintage, 2001.

Winterson, Jeanette. Why Be Happy When You Could Be Normal? London: Vintage, 2012.

\section{ABOUT THE AUTHOR}

Sarah Herbe is associate professor of British literature and culture at the department of English and American Studies, University of Salzburg. In 2017, she completed her habilitation thesis on paratextual life writing in English poetry books (to be published in 2018). Recent publications include a co-edited collection on British Autobiography in the 20th and 21st Centuries (with Gabriele Linke; 2017) and an essay on "Teaching Life-Writing in a Blended Learning Environment" $(a / b$ : Auto/biography Studies, 2018). For more information, see https://uni-salzburg.at/ ang/herbe. 